\title{
RECENT TIE UP OF SBI WITH ITS ASSOCIATES: A PROBE OF PRE AND POST-MERGER ATTAINMENT THROUGH THE LENS OF CAMELS FRAMEWORK
}

\author{
Rajashree Upadhyay \\ Research Scholar, \\ Department of Commerce, \\ Kazi Nazrul University, Asansol \\ Paschim Bardhaman, \\ West Bengal, \\ Pin - 713340
}

\author{
Dr. Mahesh Kumar Kurmi * \\ Assistant Professor, \\ Department of Commerce, \\ Kazi Nazrul University, Asansol \\ Paschim Bardhaman, \\ West Bengal, \\ Pin - 713340
}

Article DOI: https://doi.org/10.36713/epra5418

\begin{abstract}
The term 'merger' signifies the joining of two or more business concerns into a single one mainly with the purpose of generating much more effective output. But, sometimes these tie up events are done to absorb the weak entity with intention to cover up these sick entity's loopholes. Merger in banking sector is now a latest trend to take over weak banks and enhance its business capability with capturing a huge portion of competitive market. In simple terms, banks are unified to enjoy the synergy benefits of the merger. State Bank of India which is currently the most popular one public sector bank of India also witnessed such kind of consolidation events primarily with its subsidiaries banks. The almost latest tie up deal of SBI with its five subsidiaries banks \& Bharatiya Mahila Bank occurred on $1^{\text {st }}$ April 2017 is the center point of this study around which analysis is rotating with the intention to examine the impact of consolidation on this largest bank's performance through the lens of CAMELS framework. This article is purely based on secondary data and all the required facts \& figures are congregated from 'CAPITALINE- 2000 Database'. Three years pre tie up phase (i.e., from 2014-15 to 2016-17) \& three years post tie up phase (i.e., from 2017-18 to 2019-20) of State Bank India are explored in this study. The findings of the study confirms that State Bank of India has failed to enjoy the benefits of merger as it take over its own associate banks which are already have high non- performing assets. Ratios related to capital adequacy do not point any remarkable improvements in post-merger phase. Similarly, bank has failed to improve its assets quality. Except Business per Employee all the management efficiency ratios have not gained enough mileage. Overall earnings capacity and liquidity of the bank has also deteriorated after merger. As a whole it can be opined that merger has not made any significant difference in financial performance of SBI, at least in short run.
\end{abstract}

KEYWORDS: Merger \& Acquisition, CAMELS, Assets Quality, Sensitivity, Banking Sector

\section{INTRODUCTION}

From the very beginning it is found that among all the financial institutions, banking sectors are the backbone of a country's economic system and always play a macro role in financial environment of corporate bodies. Indian banking sector is the pillar of Indian economy and both the public \& private banks have their own contribution on the development of economic system. To operate business activities efficiently it is seen that every government \& non-government concerns have to require banking facilities and even in current situation each \& every individual also needs this financial institution's help for their daily smooth running monetary task .So it can be easily stated that growth in banking sector can attract enhancement in economic system and these enrichment in banking sector may be achieved by two ways i.e. internal development \& external development. Internal enlargement is also termed as organic enhancement which is mainly done by inaugurating new strategies \& techniques in banking activities, increasing the number branches \& branch facilities, expansion of market areas 
etc. Whereas external enlargement is possible by adopting restructuring strategies which is also known as inorganic enhancement .Hence for the betterment of banking sector's overall performance, they always applying both the organic \& inorganic growth strategies in their operating activities. In today's contemporary scenario, State Bank of India is the wide reaching multinational public sector bank in India. It emerged on June 1806 as Bank of Calcutta and later on in 1809 relabeled as Bank of Bengal which was funded by British Government. Since 1921, this Presidency Government funded bank showed its consolidation act because on that period Bank of Bengal unified with Bank of Bombay \& Bank of Madras and this consolidated bank is known as Imperial Bank of India which till the formation of RBI operated as Central Bank of India. In 1955, this Imperial Bank of India retitled as State Bank of India (SBI) and in 1960 it obtained control of seven banks which are termed as subsidiaries of SBI. This public sector bank had witnessed many merger events from its beginning and as we know that merger event by banking sector took place mainly for overcome the loopholes of that concern and strengthening its competitive position with long run survival. Merger means nothing but the act of joining two or more business bodies into a single one and for the welfare of public at large SBI always became part of such type of unification deal .To represented State Bank of India as a mega bank \& to reduce its subordinates continuous enhanced Non Performing Assets, its associate banks were begins to tie up with it and firstly in 2008 State Bank of Sourashtra tie up with SBI and thereafter in 2009 State Bank of Indore consolidated with SBI. Finally with effect from 1 $1^{\text {st }}$ April 2017 State Bank of India unified with its remaining five associate banks (i.e. State Bank of Bikanir \& Jaipur, State Bank of Hyderabad, State Bank of Mysore, State Bank of Patiala \& State Bank of Travancore) \& with Bharatiya Mahila Bank. These ultimate subordinate banks \& Bharatiya Mahila Bank tie up event with SBI make it the largest bank in India and insert SBI within top 50 globally banks in context of assets to compete in worldwide financial market.

The prime success of a unification deals in banking sectors are measured in terms of bank's long term survival with managerial efficiency, capturing the huge market area, remove competition, attaining sound liquidity \& profitability position and overall enjoyment of synergism. Here, through this paper, a true effort has been put to assess the outcomes of this merger on the basis of above mentioned criterion and to apprehend whether any significant improvement in performance of SBI is perceived after the merger. The structure of this paper is as follows: Section 2 takes up the summary of prior studies in form of literature review manageable in this tone, Section 3 highlights the objective of the study, Section 4 depicts the hypothesis, Section 5 makes available a look over the methodology followed, Section 6 puts focus on the findings and its interpretation, Section 7 deals with hypothesis testing and finally, the last part is concerned with the conclusion of the research.

\section{REVIEW OF EXISTING LITERATURE}

The analysis of banking performance before and after merger has received a great deal of attention especially over the last three decades in Indian Banking context. A number of researchers have used CAMELS Framework to explore the impact of merger on various financial parameters in post tie up phase but these studies provide variegated outcomes. Hence, a critical insight into the existing works on this important issue seems accurate before pacing towards this empirical study.

Raiyani (2010) in his research study "Effect of mergers on efficiency and productivity of Indian Banks : A CAMELs analysis " examined overall performance of unified banks in terms of financial parameters explained in CAMEL rating approach by taking an average of 5 years prior and 5 years after tie up financial data. Data have been gathered from secondary database package 'PROWESS'. To assess the financial attainment of the consolidated banks, this study considered six acquirer banks viz., Bank of Baroda, Punjab National Bank, and Oriental Bank of Commerce, HDFC, ICICI and CBOP as a sample of the study. Case of the consolidation of Bank of Baroda and Banaras State Bank Ltd showed that the spread of the bank has enriched in post- consolidation period which has signified favorable earning capacity of the bank but in case of burden ratios, the deterioration in average burden of the bank had not satisfied by the t-test. Similarly, profitability ratios indicated that the overall profitability of the bank had increased in after tie up phase but the liquidity position of the bank declined. The solvency ratios showed that the long term capacity of repaying debt has improved and non-performing assets of the bank has also reduced in post- unification period. The tie up case of Punjab National Bank and Nediungadi Bank Ltd reflected that the spread ratios, profitability, solvency and asset quality ratios have indicated an enriched trend in post unification phase but the liquidity ratios and burden of the bank was not so satisfactory. Consolidation of Oriental Bank of Commerce and Global Trust Bank Ltd had pointed out an improvement phase in the performance of its 
liquidity, profitability, solvency, asset quality and managerial ability in post-unification period. Study of the merger of HDFC Bank with Times Bank Ltd concluded that the spread ratios, overall profitability, solvency ratios and asset quality ratios have enriched during post-merger but the result of the burden ratios was not satisfactory same as the liquidity position of the bank. The case of consolidation event between ICICI Bank and Bank of Madura Ltd has demonstrated an enhanced overall financial attainment of the bank in post consolidation phase except Return on Net Worth Ratio. Unification deal of Centurion Bank with the bank of Punjab also proved as a good deal because the study confirmed an overall satisfactory financial performance in post- merger phase.

Ravichandran et al. (2010) through their research paper "Market Based Mergers in Indian Banking Institutions" have tried to investigate the selected banks efficiency and performance during prior consolidation phase \& post consolidation phase. The necessitate data for this research have been collected from the annual reports of those banks which were merged in the period of 2000 to 2007. They have considered seven major tie up deal and examined the financial stability of concerned banks through CRAMEL model that includes capital adequacy, resource raising ability, assets quality, management \& system evaluation, earning potential, and liquidity analysis. Data have been analyzed for 3 years pre-consolidation and 3 years post-consolidation phase. The final conclusions were drawn with the help of regression analysis \& factor analysis. Findings of this study revealed that only two variables i.e., 'Advances to total assets ratio' and 'profit margin' were highly impressive from the view point of financial stability and also significantly different in post tie up phase in comparison to pre tie up phase. Furthermore, profitability parameters have expressed negative impact of tie up on returns of the consolidated banks. Researchers remarked that the primary reason behind these take over event was to scale up their operations and increase interest income.

Kalaichelvan (2011) conducted a research investigation on "Efficacy of Merger and Acquisition in Indian Banking Industry" to measure the prior tie up $\&$ post tie up performance of unified banks in India during the period from 1993-94 to 2004-05. All the trustworthy data were taken from CMIE database. A period of three years before consolidation and three years after the consolidation have been considered to explore short term performance, whereas a period of five years before consolidation and five years after the consolidation have been used for long term performance measurement. Researcher has applied CAMEL approach along with various operating performance ratios to examine the post- unification performance. Moreover, in order to put the final observation, pre \& post attainment data have been statistically tested through parametric t-test. This study observed that in case of Capital adequacy ratios, all the merged banks (both private \& public banks) have performed well but capital adequacy ratio of Bank of Baroda have found much higher as compared to other banks. Asset quality ratios reflected that larger banks, like ICICI Bank, State Bank of India showed lesser attainment than smaller counterparts. As a whole, consolidated banks represented enhanced management efficiency in post tie up period but ICICI Bank had much better management efficiency in comparison to other unified banks. In case of earning ability, this research have emphasized over the fact of better attainment of private banks than public banks specially HDFC bank had higher earning ability as compared to other banks. It was found that all the consolidated banks enriched their liquidity position but Bank of Baroda had much favourable inclined liquidity position than other consolidated banks. Researcher concluded that both private and public unified banks have performed well in post tie up phase but it has been observed that public banks attainment was relatively better in 'assets quality' and 'liquidity management' dimension but on the other hand, private sector banks attainment was relatively better in 'Capital adequacy', 'management efficiency' and 'earning quality' dimensions.

Singh et al. (2014) through their research study "Early Warning Signals of Merger of Banks - A Case Study of Global Trust Bank (GTB) and Centurion Bank of Punjab (CBOP) in India" have made an attempt to examine the investment portfolio pattern and assets quality of sample bank in pre unification period and also have tried to assess the probable reasons and factors that leads to such consolidation. They have taken 'Global Trust Bank' and 'Centurion Bank of Punjab' as the sample of the study and obtain relevant data for 8 years from various secondary sources of respective banks. CAMEL model has been used to measure prior unification attainment of selected banks. Beside that various statistical techniques such as mean, standard deviation and unpaired t-test etc. have also been applied by them at apt places to arrive at final conclusion. The interpreted result of Global Trust Bank on various parameters of financial attainment depicted that from March 2000, an enhanced trend on 'Net NPA to Net Advances ratio' have been observed that has pointed out weak areas of such bank and losses faced by it which ultimately approaches the bank for a tie up operation. On the other hand, in case of Centurion Bank of Punjab during pre-unification period, downfall 
picture on overall performance of bank is observed. Level of Non-Performing assets has enhanced year by year which expressed deteriorated assets quality of the bank. Besides, a decreasing trend in 'Business per employee' and 'capital adequacy ratio' has also been observed. Results of t-test showed that financial health of these respective banks remarked alarming signals which automatically leads to potential unification of such banks. Overall it can be concluded that a continuous increase in Non-Performing Assets and downward trend of assets quality in before 3 to 4 years of acquisition indicated an adverse portrait of these selected banks and tie up become necessary for cover up the loopholes of such banks. It also pointed out by the researchers that if preventive measures are taken from earlier point of deterioration then may be such kind of declined image are not represented and it not so became necessary to tie up with another bank.

Tanwar (2016) gave his views on financial \& operating attainment of consolidated banks in India during pre and post tie up period through a research article "A Study on the performance analysis of banks in India after mergers and acquisitions". This article taken four unification cases which occurred between 2006-2010 namely; consolidation between Federal Bank with Ganesh Bank of Kurandwad, Indian Overseas Bank with Bharat Overseas Bank, State Bank of India with State Bank of Sourastra and ICICI with Bank of Rajasthan. In order to compare the performance of banks in pre and post tie up phase, 5 years pre and 5 years post consolidation period data had been taken. The study was based on purely secondary data which extracted from reports of RBI, respective bank's annual reports, CMIE Prowess database, Capitaline database and from websites also. To examine pre and post-unification attainment, researcher used CAMEL model which later on interpreted by adopting some statistical tools, such as; mean, standard deviation \& coefficient of variance etc. Consolidation between Federal Bank with Ganesh Bank of Kurandwad demonstrated that in case of Capital adequacy, Net NPA to Total Assets and Total Advances to Total Deposits resulted deteriorated performance in post take over period where as other parameters depicted improved attainment of the bank. In case of tie up between Indian Overseas Bank with Bharat Overseas Bank significant enhancement noticed except in case of some variables, like; Capital adequacy ratio, Net NPA to Total Assets, Profit per Employee \& Liquid assets to Total assets ratio which reflected an adverse performance on post tie up period. Capital adequacy ratio, Net NPA to Total assets, Asset quality, Return on Net worth ratio \& Liquid assets to Total assets ratio revealed downward trend of performance in post consolidation period for SBI tie up event, but other parameters represented inclined attainment due to merger deal. The result of acquisition between ICICI Bank with Bank of Rajasthan demonstrated overall upward trend on attainment activities in post tie up period except in context of Net NPA to Total Assets, Profit per Employee and Liquid assets to total deposits ratio which indicated that in post-merger phase the attainment of the bank became downward. Finally, it can be concluded that overall improvement has noticed in the performance of the consolidated banks in postunification period and these merger deals became successful at a certain context.

Veena and Patti (2017) undertook a study "Pre and Post-Merger Performance through CAMEL Rating Approach: A Case Study of ICICI Bank Ltd" to detect the financial attainment of ICICI Bank Ltd for the period from 2007-08 to 2016-17 and to assess the overall market position of the bank during postconsolidation period. This study had emphasized on indepth analysis of various dimensions of CAMEL model viz., Capital Adequacy, Asset Quality, Management Efficiency, Earning Quality \& Liquidity position in the market. Findings on this study reflected an upward trend in Capital Adequacy ratios but instead of that researchers have suggested that the bank need to enhance much more in capital adequacy to maintained greater stability in current banking scenario. In case of Asset quality, during post-unification period the bank had safest position on investments but the bank need to control its non-performing assets as per this study. Though all the management efficiency ratios are replicated a persuaded trend but the researchers still suggested that the bank should enriched its management efficiency by considering the risk perception factor. The Earnings Quality ratios have been improved after merger which showed favourable position of the bank, but 'Interest Income to Total Income' showed a declining phase in post consolidation period. Similar results have also been observed in case of 'Non Interest Income to Total Income ratio'. In post-merger phase, an upward rising trend can be observed in case of Liquidity ratios also.

Mathur and Sharma (2018) examined the significant differences between the prior \& after tie up phase financial attainment of the State Bank of India and its associates through their research paper "The CAMEL Model Analysis of Pre Merger and PostMerger Profitability of State Bank of India Ltd and It's Associates". In this study, researchers have used CAMEL approach because it considered six different dimension of performance assessment. Current tie up event of SBI and its associates took place on 31st March 2017. So, one year pre-unification and one year 
post- unification data has considered here as sample period to accomplish the objectives. The study reflected that banks were adequately capitalized before and after tie up period and 'Advances to Total Asset ratio' indicate that in post- take over period SBI given less advances from its total assets. In case of asset quality, it is found that non-performing assets has enhanced which is a bad indicator for SBI. if we look into Management efficiency scenario, the result found that the ratio of business per employee is enriched but Profit per employee, Return on Asset, Return on Equity pointed out deteriorated trend which is an adverse sign for the bank. Earnings quality of the SBI in post-merger phase exhibited declining trend which signified that these tie up event failed to generate profitability. Liquid Assets to Total Assets ratios showed upward trend which indicate that the liquidity position of the SBI has become improved. Total Deposits to Total Assets ratio is declined which denote that in post- merger period the efficiency to provide sufficient liquidity to depositors of SBI has deteriorated. As per this study, though this merger enhanced the basic network or structure of SBI but overall it failed to given a satisfied result.

Sahni et al. (2018) studied the impact of tie up between commercial banks in India during prior \& after consolidation period through their research study "Financial Performance Evaluation of Indian Commercial Banks after Merger and Acquisition". In this study, researcher mainly considered one tie up deal i.e. consolidation between HDFC Bank Ltd with Centurion Bank of Punjab Ltd. All relevant data i.e., 5 years prior and 5 years after take over data for this investigation was gathered from respective banks annual reports and through Capitaline database. Collected data are analyzed by adopting Camel model $\&$ results are evaluated by applying t-test statistical technique. The illustrated result of this paper showed that this tie up event leads to an enhancement in all capital adequacy ratios which signified that additional capital requirement capability of the unified bank had increased in after consolidation phase. Same as Asset quality reflected very well attainment which not only identified the better debt recovering ability of merged bank but also enriched assets performance. Furthermore, there is no significant improvement observed in management efficiency as most of the management efficiency ratios (i.e. Business per employee \& profit per employee) had not performed well ; that means due to tie up event employees performance had not improved. Earnings quality revealed better attainment in post-merger phase, whereas a liquidity position was not improved. Finally, it can be concluded that no significant notable improvement has observed in managerial efficiency \& liquidity ratios but in case of other parameters, an enhanced view remarked in this investigation. Overall this tie up to some extent became successful and it suggested by the researchers that in near future this study can further be extended by considering other nonfinancial factors also.

Sharma and Patel (2019) executed an investigation on "A Study on Performance Rating of SBI Group: CAMEL Model Analysis" for measuring the SBI \& its associate banks' financial attainment and ranked the selected banks on target performance basis. In this study researchers used CAMEL rating approach for 5 years period i.e. from 2010-11 to 2014-15. As per this article, in case of Capital Adequacy, Capital Adequacy Ratio is higher in State Bank of Hyderabad \& ranked 1, whereas State Bank of Patiala had less percentage of CAR; same as in Debt Equity ratio, State Bank of Hyderabad had ranked 1 whereas State Bank of Travancore ranked 6. In Advances to Total Assets ratio \& Govt. Securities to Total Investment ratio, State Bank of Bikaner \& Jaipur ranked 1 but rank 6 is given to State Bank of Hyderabad. Overall in Capital adequacy, State Bank of Bikaner \& Jaipur had better attainment than other SBI group and ranked 1, whereas SBI had ranked 6. Asset quality ratios showed that State Bank of Patiala had lowest NPA than other SBI group \& ranked 1, on the other hand SBI had poor performance on NPA which signified that it could not controlled its NPA \& ranked 6. In case of Management quality, State Bank of Travancore had great attainment with ranked 1, whereas the attainment of management team of State Bank of Mysore is not so good \& ranked 6 as per this study. If we look into the matter of Earnings quality, State Bank of Hyderabad is the profitable one with favourable position on earning ability \& ranked 1 whereas State Bank of Patiala failed to generate better earnings ability than other SBI groups and ranked six. Depend on this study, SBI had better liquidity position in the market with capacity of meet the regular financial obligations, but State Bank of Mysore had not so much liquidity position in the market \& ranked 6. As a whole, it can be said that State Bank of Hyderabad had better financial attainment than other SBI group and for that reason researchers given SBH rank 1, but in case of State Bank of India except liquidity position overall performance in context of financial indicators is not much satisfactory and provided rank six. Finally, to evaluate the above mentioned ranked result, the researchers applied Kruskal Wallis $\mathrm{H}$ Test and found that there are no significant differences noticed on performance parameters of the selected banks. This study is reflected the analysis of SBI group in a limited manner and it can be done with more detail manner. 
Gandhi et al (2020) examine post tie up attainment of ICICI bank in context of financial parameters through their research article, namely; "Post Merger Financial Performance of ICICI Bank". ICICI bank witnessed four consolidation events, i.e. consolidation between ICICI Bank with Bank of Madura (2001), ICICI Bank with ICICI Ltd (2002), ICICI Bank with Sangli Bank (2008) \& ICICI Bank with Bank of Rajasthan and these four ties up event are considered by the researchers as a sample of this investigation. This study analyzed 3 years prior unification \& 3 years post-unification data by adopting CAMEL model and the ultimate conclusion is drawn with the help of some statistical tools like; Mean, Standard deviation, t-test etc. The analyzed report of unification between ICICI Bank with Bank of Madura \& ICICI Ltd showed that there is nothing mentionable significant enhancement noticed on the financial activities in after tie up period. Same as unification between ICICI bank with Sangali bank failed to reflect any notable changes on financial attainment during post acquisition phase. While in case of acquisition with Bank of Rajasthan, the post tie up attainment of ICICI bank depicted that in Asset quality $\&$ earning ability some enriched significant differences are remarked \& rest of the parameters point out null impact of consolidation. At last, based on this study, it is seen that the entire tie up events failed to incline the financial attainment of ICICI bank.

Review of the existing works of researchers and academicians evidently confirm that literature base relating to the assessment of performance of bank before and after merger through CAMELS is quite strong in India. But, most of the studies have attempted to draw the conclusion only on the basis of first five elements of CAMELS framework. Most of them have ignored the last element i.e., Sensitivity. Besides that impact of merger on SBI with its associates and Mahila Bank Ltd is not extensively explored for a sustainable period of three years. Thus, a modest effort has been made here to bridge the gap of the existing literature in context of impact of merger on financial performance in Indian banking sector.

\section{OBJECTIVE OF THE STUDY}

To analyze pre and post-merger attainment of State Bank of India through the lens of CAMELS Framework is the precise objective of this study.

\section{HYPOTHESIS OF THE STUDY}

To accomplish the above stated goal of the study, the following null hypothesis is formulated:

There is no significant difference in the financial performance of State bank of India as per CAMELS approach before and after merger.
Rejection of the null hypothesis indicates a statistically significant difference in the financial performance of State bank of India as per CAMELS approach before and after merger.

\section{DATABASE AND METHODOLOGY OF THE STUDY}

This article is purely based on secondary data and all the required facts \& figures are congregated from 'CAPITALINE- 2000 Database'. The latest take over event of SBI occurred on 1 $1^{\text {st }}$ April 2017 is consider here as sample of study i.e. tie up between State Bank of India with its five subordinate banks \& with Bharatiya Mahila Bank is interpreted here. The five associate banks of SBI that are consolidated with it are State Bank of Bikanir \& Jaipur, State Bank of Mysore, State Bank of Travancore, State Bank of Patiala and State Bank of Hyderabad. Three years pre tie up phase (i.e., from 2014-15 to 2016-17) \& three years post tie up phase (i.e., from 2017-18 to 2019-20) of State Bank India are explored in this study.

In order to achieve the precise objective and to derive the efficacy of this consolidation during pre and post tie up period, CAMELS approach is used here. CAMELS approach is basically one kind of ratio analysis typically used by the banks for assessment of the overall attainment of the banks with indicating their strengths \& sickness by taking into account the six different dimension of performance assessment i.e. Capital Adequacy, Assets Quality, Management Potency, Earning Quality, Liquidity and Sensitivity.

Capital Adequacy emphasizes over the bank's compliance with regulations on maintenance of minimum capital funds to protect depositor's money in respective banks. Adequate level of Capital fund of banks facilitates potential as well as existing depositors in materializing their risk perception about the bank. Popular indicators of Capital Adequacy include Capital Adequacy Ratio, Debt Equity Ratio, Total Advances to Total Assets ratio and Government Securities to Total Investment Ratio

Assets Quality reflects the stability of the bank when faced any specific obstacles. Asset quality regulates the robustness of banks against any loss in value of the assets. Maintaining Asset quality is vital to banks, as the value of assets can decline speedily if they are invested or lent to a high risky endeavor. The asset quality is mainly assessed with regard to the level and severity of non-performing assets. Widespread indicators of Assets quality include Net NonPerforming Assets (NPA) to Net Advances Ratio, Gross NPA to Net Advances Ratio, Total Investments to Total Assets Ratio and Net NPA to Total Assets ratio. 
Management Potency measures the ability of the management team to categorize the potential risks and also assess the capability of management in handling those risks under emerged financial stress. In addition, management potency consists of the assessment of compliance of banks operations with set norms, capability of cope up in changing state of affairs, enough technical competence, apt leadership skills and encyclopedic administrative ability. Management soundness can be judged through ratios like Total Expenditure to Total Income Ratio, Total Advances to Total Deposits Ratio, Total Income to Total Assets Ratio, Profit per Employee and Business per Employee. Earnings Quality expresses the degree of the parameters identifying the association between Net Income with quality criteria of the respective banks. Resilient earnings position of banks replicates the capability to backing present and future operations. Worthy earning quality, facilitates the banks to absorb future losses, distribute apt rate of dividends to its shareholders, and anticipate an optimum level of Capitalization. Various ratios for measuring the worth of earnings are Dividend Payout Ratio, Net Profit to Assets ratios, Return on Equity, Spread to Total Assets, and Interest Income to Total Income and Non-Interest Income to Total Income.

Liquidity examines the interest rate risk and liquidity risk associated with the operations of Bank. Interest rates risk affects the earnings and if the exposure to interest rate risk is huge, then the bank's portfolio value related to investment and loan will be much volatile. Liquidity risk is the risk arises when banks are not being able to meet short term obligations as well as unanticipated funds that are claimed by depositors. The most commonly used ratios to evaluate liquidity of bank's are Cash to Deposit Ratio, Government Securities to Total Assets Ratio, Total Investment to Total Deposit Ratio, Liquid Assets to Total Assets Ratio and Liquid Assets to Deposit Ratio.

Sensitivity measures the extent to which the bank is sensitive to market risks. Market Risk involves exposures associated with changes in interest rates, foreign exchange rates, and equity prices. Sensitivity reflects the degree to which earnings are affected by change in interest rates, exchange rates, and share prices. Sensitive to market risks reflects institution's exposure to interest rate risk, foreign exchange volatility and equity price risks. Sensitivity of a bank can be assessed through, Beta, Price Earnings Ratio, Interest Rate Gap Analysis, Long term deposit to deposit Ratio and demand Deposit to Deposit Ratio.

To achieve the precise objective of the study and to test the research hypothesis, paired $t$ test have been used here.

\section{MAJOR FINDINGS OF THE STUDY} 6.1 Interpretation of Capital Adequacy Ratios of SBI during Pre and Post-Merger

Table 1: Capital Adequacy Ratios of SBI during Pre and Post-Merger:

\begin{tabular}{|l|c|c|c|c|c|c|}
\hline \multirow{2}{*}{ Particulars } & \multicolumn{3}{c|}{ Pre-Merger } & \multicolumn{3}{c|}{ Post -merger } \\
\cline { 2 - 7 } & $\mathbf{2 0 1 4 - 1 5}$ & $\begin{array}{c}\mathbf{2 0 1 5} \\
\mathbf{1 6}\end{array}$ & $\begin{array}{c}\mathbf{2 0 1 6 -} \\
\mathbf{1 7}\end{array}$ & $\mathbf{2 0 1 7 - 1 8}$ & $\begin{array}{c}\mathbf{2 0 1 8 -} \\
\mathbf{1 9}\end{array}$ & $\begin{array}{c}\mathbf{2 0 1 9 -} \\
\mathbf{2 0}\end{array}$ \\
\hline Capital Adequacy Ratio (\%) - Basel II & 12.79 & 13.94 & 13.56 & 12.74 & 12.85 & 13.13 \\
\hline Debt-Equity Ratio & 13.87 & 14.24 & 15.08 & 15.79 & 16.89 & 17.08 \\
\hline Total Advances to Total Assets Ratio & 0.63 & 0.62 & 0.58 & 0.56 & 0.59 & 0.59 \\
\hline $\begin{array}{l}\text { Government Securities to Total } \\
\text { Investment Ratio }\end{array}$ & 0.80 & 0.82 & 0.76 & 0.81 & 0.80 & 0.78 \\
\hline
\end{tabular}

While analyzing three years prior merger phase (2014-15 to 2016-17) \& three years post-merger phase (2017-18 to 2019-20) financial attainment, from Table 1 it is noticed that in case of Capital Adequacy ratio on an average trifling fluctuation observe. This Capital adequacy ratio varies from 12.79 to 13.13 in the whole interpretation period. It is also seen that just before the merger event the performance of capital adequacy ratio also satisfies i.e. 13.56 but after the tie up event it deteriorates in 2017-18 at 12.74 per cent but thereafter a little improvement is detected \& ultimately in 2019-
20 it stands at 13.13 per cent. So, overall a huge enhancing Capital adequacy is not remarkable in this evaluation which means in this assessment a moderate change is notable with average capability to protect depositor's money. However, Capital adequacy ratio both in pre and post-merger are higher than the standard ratio prescribed by Basal II and RBI guideline which indicate that bank is adequately capitalized before and after merger. Debt Equity ratio reflects a change from 13.87 to 17.08 and it is visible that in after tie up phase this ratio is gradually increased from 
15.08 to 17.08 . The enhancing trend of debt equity ratio is an adverse sign of performance of SBI as high debt equity ratio denotes higher degree of financial leverage and less protection for the depositors and creditors. A slight deteriorate trend has reflected in Total advances to Total Assets ratio from 2014-15 to 2019-20; but at the time of merger deal it become 0.58 \& thereafter 0.56 in 2017-18 and again in 2018-19 \& 2019-20 it stands at 0.59 . This submissive attitude of bank towards total advances out of total assets indicates that banks have not tried to make extra earning by giving out more advances. Government
Securities to Total Investment ratio which mainly analyze the risk taking capability of the banks, as more investment in Government securities denotes maximum amount of investment in low risky investment and Assets, demonstrates a very little variation here which is a good indication for the depositors of the bank. In 2014-2015 it was 0.80, while at the time of consolidation event it stands at 0.76 and finally after the tie up deal it fluctuates from 0.81 to 0.78 . As reported, more investment in Government securities denotes maximum amount of investment in low risky investment and Assets. .

\subsection{Interpretation of Assets Quality Ratios of SBI during Pre and Post-Merger} Table 2: Assets Quality Ratios of SBI during Pre and Post-Merger:

\begin{tabular}{|l|c|c|c|c|c|c|}
\hline \multirow{2}{*}{ Particulars } & \multicolumn{3}{|c|}{ Pre -Merger } & \multicolumn{3}{c|}{ Post -merger } \\
\cline { 2 - 7 } & $\begin{array}{c}\mathbf{2 0 1 4 -} \\
\mathbf{1 5}\end{array}$ & $\begin{array}{c}\mathbf{2 0 1 5 -} \\
\mathbf{1 6}\end{array}$ & $\begin{array}{c}\mathbf{2 0 1 6 -} \\
\mathbf{1 7}\end{array}$ & $\mathbf{2 0 1 7 - 1 8}$ & $\begin{array}{c}\mathbf{2 0 1 8 -} \\
\mathbf{1 9}\end{array}$ & $\begin{array}{c}\mathbf{2 0 1 9 -} \\
\mathbf{2 0}\end{array}$ \\
\hline Net NPA to Net Advances Ratio (\%) & 2.12 & 3.81 & 3.71 & 5.73 & 3.01 & 2.23 \\
\hline Gross NPA to Net Advances Ratio (\%) & 4.36 & 6.71 & 7.15 & 11.55 & 7.90 & 6.41 \\
\hline $\begin{array}{l}\text { Total Investment to Total Assets Ratio } \\
(\%)\end{array}$ & 23.48 & 24.38 & 28.31 & 30.61 & 26.19 & 26.44 \\
\hline Net NPA to Total Assets Ratio (\%) & 1.34 & 2.36 & 2.15 & 3.20 & 1.78 & 1.31 \\
\hline
\end{tabular}

In case of Assets Quality ratios as depicted in Table 2, Net NPA (Non-Performing Assets) to Net Advances ratio Changes from 2.12 per cent in 2014-15 to 2.23 per cent in 2019-20. It is also recognized that just after the merger phase in 2017-18 this ratio have increased to 5.73 and thereby has decreased in 2018-19 to 3.01 per cent \& in $2019-20$ to 2.23 per cent. Gross NPA to Net Advances ratio depicts same picture like Net NPA ratio; after tie up event Gross NPA ratio enhanced from 7.15 to 11.55 \& thereafter in 2018-19 \& 2019-20 it shows deterioration i.e. in 2018-19 it is 7.90 $\&$ in 2019-20 it become 6.41 . The foremost anxiety of bank is to keep the amount of non-performing assets to its low level because growing NPAs is a challenge to bank, which will adversely affect the profitability of bank. From prior unification to post-unification period, the report of Total Investment to Total Assets ratio have not given satisfied result as just after the consolidation event firstly this ratio has enriched from 28.31 to 30.62 , and in $2018-19$ it stands at 26.19 \& again after a bit enhancement in 2019-20 it become 26.44. Total Investment to Total Asset ratio indicates here that the bank have not conservatively kept major shield of investments to guard against NPAs. At the time of merger deal Net NPA to Total Assets ratio was 2.15 per cent, then after the tie up event in 2017-18 it become 3.20 per cent which is the sign of poor performance of NPAs Management in the bank but thereafter it become 1.78 per cent \& 1.31 per cent respectively in 2018-19 \& 2019-20.

\subsection{Interpretation of Management Potency Ratios of SBI during Pre and Post-Merger} Table 3: Management Potency Ratios of SBI during Pre and Post-Merger:

\begin{tabular}{|l|c|c|c|c|c|c|}
\hline \multirow{2}{*}{ Particulars } & \multicolumn{3}{c|}{ Pre-Merger } & \multicolumn{3}{c|}{ Post -merger } \\
\cline { 2 - 7 } & $\mathbf{2 0 1 4 - 1 5}$ & $\mathbf{2 0 1 5 - 1 6}$ & $\mathbf{2 0 1 6 - 1 7}$ & $\mathbf{2 0 1 7 - 1 8}$ & $\mathbf{2 0 1 8 - 1 9}$ & $\mathbf{2 0 1 9 - 2 0}$ \\
\hline Total Expenditure to Total Income Ratio & 0.9251 & 0.9481 & 0.9503 & 1.0247 & 0.9969 & 0.9521 \\
\hline Total Advances to Total Deposit Ratio & 0.8058 & 0.8457 & 0.7683 & 0.7149 & 0.7508 & 0.7173 \\
\hline Total Income to Total Assets Ratio & 0.0853 & 0.0812 & 0.0780 & 0.0765 & 0.0757 & 0.0764 \\
\hline Profit per Employee (Cr.) & 0.0614 & 0.0479 & 0.0500 & -0.0248 & 0.0034 & 0.0581 \\
\hline Business per Employee (Cr.) & 13.66 & 15.38 & 17.25 & 17.58 & 19.81 & 22.32 \\
\hline
\end{tabular}

At the time of the assessment of Management Efficiency ratios, Table 3 clearly exhibits that just after the consolidation event, Total Expenditure to Total Income ratio has increased from 0.9503 to 1.0247 but 
later on SBI controls it again \& in 2019-20 it become 0.9521. In case of Total Advances to Total Deposit Ratio a very little downward change has detected from just before merger phase to post merger phase i.e. from 0.7683 to 0.7179 and during total sample period it varies from 0.8058 to 0.7173 . This adverse trend of Total Advances to total Deposit ratio expresses that the efficiency of the bank's management in utilization of the deposits available into advances has decreased. A fluctuation is also recognized in Total Income to Total Assets ratio but after merger period SBI control these fluctuations to some extent because in 2017-18 this ratio was 0.0765 , then in 2018-19 it becomes 0.0757 and finally in 2019-20 it stands at 0.0764. Downward move of Total Income to Total Assets ratio indicates poor management of assets for earning profit in the firm. In terms of Profit per employee, just after the tie up event, negative report i.e. -0.0248 is monitored which signifies that due to merger event the efficiency of the employees have declined and this may be for the reason of changing working environment or job status. But from 2018-19 SBI focuses on its management efficiency area \& from negative report it again comes into positive view i.e. $0.0034 \&$ ultimately in $2019-20$ it become 0.0581. In case of Business per Employee, favorable differences are recognized from pre tie up to post tie up phase i.e. from 13.66 to 22.32 . This denotes that SBI has improved its business efficiency which is a positive sign for the bank.

\subsection{Interpretation of Earning Quality Ratios of SBI during Pre and Post-Merger} Table 4: Earning Quality Ratios of SBI during Pre and Post-Merger:

\begin{tabular}{|l|c|c|c|c|c|c|}
\hline \multirow{2}{*}{\multicolumn{1}{|c|}{ Particulars }} & \multicolumn{3}{c|}{ Pre-Merger } & \multicolumn{3}{c|}{ Post -merger } \\
\cline { 2 - 7 } & $\begin{array}{c}\mathbf{2 0 1 4 -} \\
\mathbf{1 5}\end{array}$ & $\begin{array}{c}\mathbf{2 0 1 5 -} \\
\mathbf{1 6}\end{array}$ & $\begin{array}{c}\mathbf{2 0 1 6 -} \\
\mathbf{1 7}\end{array}$ & $\mathbf{2 0 1 7 - 1 8}$ & $\begin{array}{c}\mathbf{2 0 1 8 -} \\
\mathbf{1 9}\end{array}$ & $\begin{array}{c}\mathbf{2 0 1 9 -} \\
\mathbf{2 0}\end{array}$ \\
\hline Dividend Pay-out Ratio (\%) & 20.62 & 20.98 & 19.77 & 0.00 & 0.00 & 0.00 \\
\hline Return to Assets (\%) & 0.64 & 0.42 & 0.39 & -0.19 & 0.02 & 0.37 \\
\hline Return on Equity (\%) & 10.20 & 6.90 & 6.69 & -3.37 & 0.44 & 6.96 \\
\hline Spread to Total Assets (\%) & 2.68 & 2.42 & 2.29 & 2.16 & 2.39 & 2.48 \\
\hline Interest Income to Total Income (\%) & 87.10 & 85.49 & 83.19 & 83.18 & 86.85 & 85.05 \\
\hline Non-Interest Income to Total Income (\%) & 12.90 & 14.51 & 16.81 & 16.82 & 13.15 & 14.95 \\
\hline
\end{tabular}

Table 4 exhibits earning quality ratios of SBI during pre and post-merger period. Earning quality of SBI specially profitability of SBI is highly affected due to merger and owing to negative earning after merger, bank has not paid any dividend to their shareholders. It is noticed that only in the prior unification phase dividend has been paid but after the tie up Dividend per Share reflects 'zero'. Similarly, a declining trend may also be observed during post tie up phase in case of Return to Assets and Return on Equity. Return to Assets became negative after the takeover and report 0.19 per cent return against the assets. Return on equity also has adverse value just after the tie up deal i.e. -3.37. However, SBI has recovered this loss soon and in 2019-20 a great improvement in ROE having 6.96 per cent is observed which signifies that even though SBI fails to generate returns for its shareholders after merger but thereafter specially in 2019-20, the bank has cover up its loopholes. Spread to Total Assets ratio reveals very slight changes in post consolidation phase in comparison with pre consolidation phase which denotes that moderate earnings given the total assets. Interest income to Total Income ratio, just prior to unification event was 83.19 per cent but after the takeover deal it stands at 83.18 per cent. Thereafter improvements observe in this ratio in 2018-19 but again this ratio has declined. A similar pattern can also be seen in case of non-interest income to total income ratio which implies that merger has not recognized any remarkable improvement in non-interest income. 
6.5 Interpretation of Liquidity Ratios of SBI during Pre and Post-Merger Table 5: Liquidity Ratios of SBI during Pre and Post-Merger:

\begin{tabular}{|l|c|c|c|c|c|c|}
\hline \multirow{2}{*}{ Particulars } & \multicolumn{3}{|c|}{ Pre -Merger } & \multicolumn{3}{c|}{ Post -merger } \\
\cline { 2 - 7 } & $\begin{array}{c}\mathbf{2 0 1 4 -} \\
\mathbf{1 5}\end{array}$ & $\begin{array}{c}\mathbf{2 0 1 5 -} \\
\mathbf{1 6}\end{array}$ & $\begin{array}{c}\mathbf{2 0 1 6 -} \\
\mathbf{1 7}\end{array}$ & $\begin{array}{c}\mathbf{2 0 1 7 -} \\
\mathbf{1 8}\end{array}$ & $\begin{array}{c}\mathbf{2 0 1 8 -} \\
\mathbf{1 9}\end{array}$ & $\begin{array}{c}\mathbf{2 0 1 9} \\
\mathbf{2 0}\end{array}$ \\
\hline Cash to Deposit Ratio (\%) & 7.18 & 7.49 & 6.26 & 5.56 & 6.08 & 5.14 \\
\hline Govt. Securities to Total Assets Ratio (\%) & 18.69 & 19.88 & 21.58 & 24.78 & 20.95 & 20.72 \\
\hline Total Investment to Total Deposit Ratio (\%) & $\mathbf{2 9 . 8 6}$ & $\mathbf{3 3 . 2 6}$ & $\mathbf{3 7 . 4 6}$ & $\mathbf{3 9 . 2 0}$ & $\mathbf{3 3 . 2 2}$ & $\mathbf{3 2 . 3 0}$ \\
\hline Liquid Assets to Total Assets Ratio (\%) & $\mathbf{7 . 5 4}$ & $\mathbf{7 . 0 9}$ & $\mathbf{6 . 3 6}$ & $\mathbf{5 . 5 4}$ & $\mathbf{6 . 0 3}$ & $\mathbf{6 . 3 4}$ \\
\hline Liquid Assets to Deposit Ratio (\%) & $\mathbf{9 . 5 9}$ & $\mathbf{9 . 6 8}$ & $\mathbf{8 . 4 1}$ & $\mathbf{7 . 0 9}$ & $\mathbf{7 . 6 4}$ & $\mathbf{7 . 7 5}$ \\
\hline
\end{tabular}

Table 5 indicates the liquidity position of SBI during entire sample period. It is witnessed that Cash to Deposit ratio have dropping attainment in post tie up period in comparison to pre tie up phase i.e. from 7.18 to 5.14 which indicates that capacity to generate loan from deposit has increased and cash reserve has weakened. Government Securities to Total Assets ratio have 21.58 per cent value in 2016-17 which has improved and become 24.78 after merger which specifies that more investment has been made in more liquid and secure risk free assets. Total Investment to Total Deposit ratio has gained momentum with 39.20 per cent after the takeover event but again goes decline. Liquid assets to Total assets ratio is also declining from 6.36 per cent in 2016-17 to 5.54 per cent in 2017-18 and thereafter stands at $6.03 \& 634$ respectively in 2018-19 and 2019-20 which designates that merger deal does not bring any remarkable improvement in overall liquidity position of the SBI. It is also recognized that Liquid Assets to Deposit ratio have deteriorating attainment in post consolidation phase which signifies that the capability of SBI in terms of liquidity for the depositors of the bank has decreased.

6.6 Interpretation of Sensitivity Ratios of SBI during Pre and Post-Merger Table 6: Sensitivity Ratios of SBI during Pre and Post-Merger:

\begin{tabular}{|l|c|c|c|c|c|c|}
\hline \multirow{2}{*}{\multicolumn{1}{|c|}{ Particulars }} & \multicolumn{3}{c|}{ Pre-Merger } & \multicolumn{3}{c|}{ Post -merger } \\
\cline { 2 - 7 } & $\begin{array}{c}\mathbf{2 0 1 4 -} \\
\mathbf{1 5}\end{array}$ & $\begin{array}{c}\mathbf{2 0 1 5 -} \\
\mathbf{1 6}\end{array}$ & $\begin{array}{c}\mathbf{2 0 1 6 -} \\
\mathbf{1 7}\end{array}$ & $\begin{array}{c}\mathbf{2 0 1 7 -} \\
\mathbf{1 8}\end{array}$ & $\begin{array}{c}\mathbf{2 0 1 8 -} \\
\mathbf{1 9}\end{array}$ & $\begin{array}{c}\mathbf{2 0 1 9} \\
\mathbf{2 0}\end{array}$ \\
\hline Price Earnings Ratio & 19.14 & 23.50 & 21.79 & -32.61 & 330.72 & 12.13 \\
\hline $\begin{array}{l}\text { Interest Rate Gap Analysis or Risk Sensitive } \\
\text { Assets to Risk Sensitive Liabilities Ratio }\end{array}$ & 1.02 & 1.01 & 1.01 & 0.99 & 0.97 & 0.97 \\
\hline Beta & 1.5214 & 1.4418 & 1.4825 & 1.8849 & 1.3673 & 1.2192 \\
\hline Long term deposit to total Deposit (\%) & 57.33 & 57.38 & 55.43 & 55.51 & 55.43 & 55.77 \\
\hline Demand Deposit to total deposit (\%) & 7.72 & 8.08 & 7.45 & 7.03 & 7.07 & 7.01 \\
\hline
\end{tabular}

Table 6 specifies the sensitivity exposure of SBI towards Market Risk during pre and post-merger. It is observed that Price Earning Ratio suddenly dropped at -32.61 after tie up event that could easily be labeled a "vote of no confidence" by the market on the stock price of SBI. Again in year next to the merger the Price Earning Ratio has unexpectedly increased to 330.72 that mirrors "over optimistic vote" by the market on the stock price of SBI and it could increase the market risk and hurt the investors in near future. A high variation in Price Earning Ratio of SBI after merger signals its unexpected exposure of share price. Risk Sensitive Assets to Risk Sensitive Liabilities Ratio or Interest rate Gap exposes a noteworthy impact of interest rate over earnings of SBI after merger. Besides, significant difference in this ratio is also noted during post- merger phase in comparison to pre-merger phase which reflects that net interest income have changed due to interest rate change. Normally, this ratio with value 1 is regarded as balanced position of bank in terms of interest rate effect as in this situation the amount of repricing assets are exactly offset by the repricing liabilities. However, during pre-tie up phase the Risk Sensitive Assets to Risk Sensitive Liabilities Ratio was more than 1 which indicates bank's assets sensitiveness as assets reprice or mature faster than liabilities but in post tie phase Risk Sensitive Assets to Risk Sensitive Liabilities Ratio reflects the value less than 1 which shows that bank's Liabilities sensitiveness as liabilities reprice quicker than assets. Beta values throughout the 
sample period show that SBI stock is High Beta Stock which reflects high risk for investor. It is seen that just after merger the stock volatility has increased to a large extent because beta value increased to 1.8849 in 2017 18 from 1.4825 in 2016-17 which adds addition risk to the stock but again it goes down 1.2192 which indicates that stock is highly volatile and sensitive. Long term deposit to total Deposit Ratio indicates how far bank is vulnerable to use fund for long term investment proposal. SBI records a high Long term deposit to total Deposit Ratio both in pre-merger and also in postmerger period which indicate that bank is consistent and secure to a large extent even after merger in using fund for long term investment. Demand deposit to total Deposit Ratio reflect how much risk bank has be bear on daily basis to meet its obligation towards depositors in form of demand deposit. SBI records a less and comparatively stable Demand Deposit to Total Deposit Ratio even after merger.

\section{HYPOTHESIS TESTING}

To achieve the specific objective of the study and to test the research hypothesis, paired $t$ test has been applied. Here entire sample period have categorised into pre- merger and post-merger and all financial parameters of CAMELS framework have been divided accordingly into two categories i.e., before merger and after merger. In before merger, three years data for all financial parameters from 2014-15 to 2016-17 has been considered and in after merger, three years data for all financial parameters from 2017-18 to 2019-20 have been used.

Table 7: Paired Samples Test of State Bank of India (Pre and Post-Merger)

\begin{tabular}{|c|c|c|c|c|c|c|c|c|c|}
\hline & \multicolumn{5}{|c|}{ Paired Differences } & \multirow{3}{*}{$t$} & \multirow{3}{*}{ df } & \multirow{3}{*}{$\begin{array}{l}\text { Sig. } \\
(2- \\
\text { tailed) }\end{array}$} \\
\hline & & \multirow[t]{2}{*}{ Mean } & \multirow[t]{2}{*}{$\begin{array}{c}\text { Std. } \\
\text { Deviation }\end{array}$} & \multirow{2}{*}{$\begin{array}{l}\text { Std. } \\
\text { Error } \\
\text { Mean }\end{array}$} & \multicolumn{2}{|c|}{$\begin{array}{l}\text { 95\% Confidence } \\
\text { Interval of the } \\
\text { Difference }\end{array}$} & & & \\
\hline & & & & & Lower & Upper & & & \\
\hline \multirow{4}{*}{ 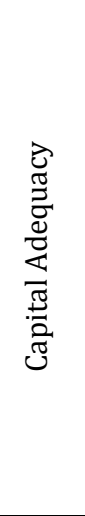 } & $\begin{array}{l}\text { Capital } \\
\text { Adequacy } \\
\text { Ratio (\%) }\end{array}$ & .5233 & .5262 & .3038 & -.7839 & 1.8306 & 1.722 & 2 & .227 \\
\hline & $\begin{array}{l}\text { Debt Equity } \\
\text { Ratio }\end{array}$ & -2.1900 & .4003 & .2311 & -3.1845 & -1.1954 & -9.474 & 2 & .011 \\
\hline & $\begin{array}{l}\text { Total } \\
\text { Advances to } \\
\text { Total Assets } \\
\text { Ratio } \\
\end{array}$ & .0321 & .0412 & .0238 & -.0702 & .1346 & 1.351 & 2 & .309 \\
\hline & $\begin{array}{l}\text { Government } \\
\text { Securities to } \\
\text { Total } \\
\text { Investment } \\
\text { Ratio }\end{array}$ & -.0063 & . 0194 & .0112 & -.0546 & .0420 & -.564 & 2 & .630 \\
\hline \multirow{4}{*}{ 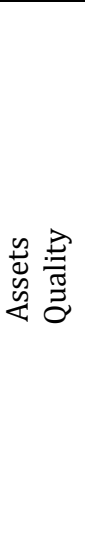 } & $\begin{array}{l}\text { Net NPA to } \\
\text { Net } \\
\text { Advances } \\
\text { Ratio (\%) }\end{array}$ & .4433 & 2.7607 & 1.5939 & -6.4147 & 7.3015 & . 278 & 2 & .807 \\
\hline & $\begin{array}{l}\text { Gross NPA to } \\
\text { Net Advances } \\
\text { Ratio (\%) }\end{array}$ & 2.5469 & 4.1306 & 2.3848 & -7.7141 & 12.8080 & 1.068 & 2 & .397 \\
\hline & $\begin{array}{l}\text { Total } \\
\text { Investment } \\
\text { to total } \\
\text { Assets Ratio } \\
(\%)\end{array}$ & 2.3595 & 4.5216 & 2.6105 & -8.8728 & 13.5919 & .904 & 2 & .461 \\
\hline & $\begin{array}{l}\text { Net NPA to } \\
\text { Total Assets } \\
\text { Ratio (\%) }\end{array}$ & 1438 & 1.4865 & .8582 & -3.5489 & 3.8365 & .168 & 2 & .882 \\
\hline
\end{tabular}




\begin{tabular}{|c|c|c|c|c|c|c|c|c|c|}
\hline \multirow{5}{*}{ 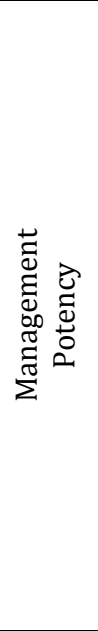 } & $\begin{array}{l}\text { Total } \\
\text { Expenditure } \\
\text { to Total } \\
\text { Income Ratio }\end{array}$ & .0500 & .0489 & .0282 & -.0714 & .1715 & 1.773 & 2 & .218 \\
\hline & $\begin{array}{l}\text { Total } \\
\text { Advances to } \\
\text { Total Deposit } \\
\text { Ratio }\end{array}$ & -.0789 & .0242 & .0140 & -.1392 & -.0186 & -5.636 & 2 & .030 \\
\hline & $\begin{array}{l}\text { Total Income } \\
\text { to Total } \\
\text { Assets Ratio }\end{array}$ & -.0052 & . 0036 & .0020 & -.0143 & .0037 & -2.524 & 2 & .128 \\
\hline & $\begin{array}{l}\text { Profit Per } \\
\text { Employee } \\
\text { (Cr.) }\end{array}$ & -.0409 & .0472 & .0272 & -.1582 & .0764 & -1.500 & 2 & .272 \\
\hline & $\begin{array}{l}\text { Business Per } \\
\text { Employee } \\
\text { (Cr.) }\end{array}$ & 4.4719 & . .5745 & .3317 & 3.0445 & 5.8992 & 13.480 & 2 & .005 \\
\hline \multirow{6}{*}{ 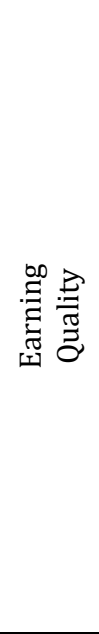 } & $\begin{array}{l}\text { Dividend Pay- } \\
\text { out Ratio (\%) }\end{array}$ & $\begin{array}{c}- \\
20.4603 \\
\end{array}$ & .6228 & .3596 & -22.0076 & -18.9131 & $\begin{array}{c}- \\
56.896 \\
\end{array}$ & 2 & .000 \\
\hline & $\begin{array}{l}\text { Return on } \\
\text { Assets (\%) }\end{array}$ & -.4143 & .4053 & .2340 & -1.4211 & .5924 & -1.771 & 2 & .219 \\
\hline & $\begin{array}{l}\text { Return on } \\
\text { Equity (\%) }\end{array}$ & -6.5863 & 6.9210 & 3.9958 & -23.7791 & 10.6064 & -1.648 & 2 & .241 \\
\hline & $\begin{array}{l}\text { Spread to } \\
\text { Total Assets } \\
\text { Ratio (\%) }\end{array}$ & -.1190 & .3663 & .2115 & -1.0291 & .7911 & -.563 & 2 & .630 \\
\hline & $\begin{array}{l}\text { Interest } \\
\text { Income to } \\
\text { Total Income } \\
\text { Ratio (\%) }\end{array}$ & -.2332 & 3.2037 & 1.8496 & -8.1917 & 7.7251 & -.126 & 2 & .911 \\
\hline & $\begin{array}{l}\text { Non-Interest } \\
\text { Income to } \\
\text { Total Income } \\
\text { Ratio (\%) }\end{array}$ & .2322 & 3.2046 & 1.8502 & -7.7285 & 8.1931 & .126 & 2 & .912 \\
\hline \multirow{5}{*}{ 莺 } & $\begin{array}{l}\text { Cash to } \\
\text { Deposit Ratio } \\
(\%)\end{array}$ & -1.3861 & .2541 & 1467 & -2.0174 & -.7548 & -9.448 & 2 & .011 \\
\hline & $\begin{array}{l}\text { Government } \\
\text { Securities to } \\
\text { Total Assets } \\
\text { Ratio (\%) } \\
\end{array}$ & 2.0990 & 3.5906 & 2.0730 & -6.8205 & 11.0186 & 1.013 & 2 & .418 \\
\hline & $\begin{array}{l}\text { Total } \\
\text { Investment to } \\
\text { Total Deposit } \\
\text { Ratio (\%) }\end{array}$ & 1.3781 & 7.3553 & 4.2466 & -16.8936 & 19.6499 & .325 & 2 & .776 \\
\hline & $\begin{array}{l}\text { Liquid Assets } \\
\text { to Total } \\
\text { Assets Ratio } \\
(\%)\end{array}$ & -1.0291 & .9963 & .5752 & -3.5040 & 1.4458 & -1.789 & 2 & .215 \\
\hline & $\begin{array}{l}\text { Liquid Assets } \\
\text { to Deposit } \\
\text { Ratio (\%) }\end{array}$ & -1.7321 & 9572 & .5526 & -4.1100 & .6456 & -3.134 & 2 & .088 \\
\hline \multirow{3}{*}{ 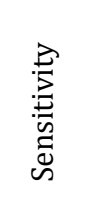 } & $\begin{array}{l}\text { Price } \\
\text { Earnings } \\
\text { Ratio } \\
\end{array}$ & 81.9399 & 196.2334 & 113.2954 & $\begin{array}{c}- \\
405.5310 \\
\end{array}$ & 569.4108 & .723 & 2 & .545 \\
\hline & $\begin{array}{l}\text { Interest Rate } \\
\text { Gap }\end{array}$ & -.0386 & . 0072 & .0041 & -.0565 & -.0207 & -9.275 & 2 & .011 \\
\hline & Beta & .0088 & .3212 & .1854 & -.7891 & .8067 & .048 & 2 & .966 \\
\hline
\end{tabular}




\begin{tabular}{|c|c|c|c|c|c|c|c|c|}
\hline $\begin{array}{l}\text { Long term } \\
\text { Deposit to } \\
\text { Deposit Ratio } \\
(\%)\end{array}$ & -1.1433 & 1.2880 & .7436 & -4.3430 & 2.0563 & -1.537 & 2 & .264 \\
\hline $\begin{array}{l}\text { Demand } \\
\text { Deposit to } \\
\text { Deposit Ratio } \\
(\%)\end{array}$ & -.7152 & .2817 & .1626 & -1.4150 & -.0153 & -4.397 & 2 & .048 \\
\hline
\end{tabular}

Table 7 exposes the paired sample test for all financial parameters of CAMELS framework in premerger and post-merger phase. While testing the paired $t$ test, significance level of 0.05 is chosen and the two tailed test is opted in this case. The significance value which is more than the 0.05 indicates non rejection of the hypothesis that states that there is no significant difference in the financial performance of State bank of India as per CAMELS model before and after merge. However, significance value for only six variables under various parameters i.e., Debt Equity Ratio, Total Advances to Total Deposit Ratio, Business Per Employee, Dividend Pay-out Ratio, Cash to deposit Ratio and Interest rate Gap is less than 0.05 which indicates a statistical significant difference in financial performance in post-merger phase in comparison to pre-merger. It is noticeable that most of the financial variables under different parameters of CAMELS are not statistically significant.

\section{CONCLUSION}

In this study, CAMELS Framework was employed to investigate pre and post-merger attainment of State Bank of India. The findings of the study confirms that State Bank of India has failed to enjoy the benefits of merger as it take over its own associate banks which are already have high non- performing assets. Ratios related to capital adequacy do not point any remarkable improvements in post-merger phase rather the increasing trend of Debt Equity Ratio has increased the degree of financial leverage and reduced the protection for the depositors and creditors. Similarly, bank has failed to improve its assets quality because non-performing assets has increased after tie up that may create challenge to bank. Except Business per Employee all the management efficiency ratios have not gained enough mileage. Overall earnings capacity and liquidity of the bank has also deteriorated after merger. After the merger the net profit has been declined and owing to negative earning after merger, bank has not paid any dividend to their shareholders. Though, the bigger size of newly merged SBI will get the benefit of large scale operation and will share high proportion of market share but at present as a whole, it can be opined that merger has not made any significant difference in financial performance of SBI, at least in short run.

\section{REFERENCES}

1. Raiyani (2010), "Effect of mergers on efficiency and productivity of Indian Banks: A CAMELS analysis", Asian Journal of Management Research, pp. 772-794.

2. Mathur, and Sharma, A. (2018), "The CAMEL Model Analysis of Pre Merger and Post Merger Profitability of State Bank of India Ltd and its Associates". Global Economy: Opportunities and Challenges, pp. 177-188.

3. Sharma, S., and Patel, A. K. (2019), "A Study on Performance Rating of SBI Group: CAMEL Model Analysis", ZENITH International Journal of Multidisciplinary Research, Vol 9, pp. 9-21.

4. Veena, K. P., and Patti, S. N. (2017), "Pre and Post Merger Performance through CAMEL Rating Approach : A Case Study of ICICI Bank Ltd", International Journal of Engineering and Management Research, Vol 7, pp. 84-92.

5. Tanwar, N. (2016), "A Study on the performance analysis of banks in India after mergers and Acquisitions", International Journal of Commerce and Management Research, Vol. 2, pp. 37-40.

6. Sahni, D., and Gambhir, S. (2018), "Financial Performance Evaluation of Indian Commercial Banks after Merger And Acquisition", Gurukul Business Review, Vol. 14, pp. 26-36.

7. Singh, K., and Singh, P. (2014), “ Early Warning Signals of Merger of Banks - A Case Study of Global Trust Bank (GTB) and Centurion Bank of Punjab (CBOP) in India", International Journal of Financial Management, Vol. 4, pp. 49-55.

8. Ravichandran, K., Nor, F., and Said, R. (2010), "Market Based Mergers in Indian Banking Institutions", International Research Journal of Finance and Economics, pp $30-39$.

9. Kalaichelvan, K. (2011), "Efficacy of Merger and Acquisition in Indian Banking Industry", PhD thesis submitted in Pondicherry University, August 2011.

10. Gandhi, V., Mehta, V., and Chhajer, P. (2020), "Post Merger Financial Performance of ICICI Bank", International Journal of Management, Vol. 7, pp. 23-35. 